\title{
Laboratory Evaluation of some Insecticides against Larval and Adult Stages of Red Palm Weevil's Rhynchophorus ferrugineus (Olivier)
}

\author{
Mohamed. S. Shawir ${ }^{1}$, Moustafa Abdel-latif Abbassy ${ }^{2}$ and Yehia Mohamed Salem ${ }^{2}$
}

\begin{abstract}
The toxicity of eight compounds belong to different groups of insecticides; chlorpyrifos-ethyl and dimethoate (organophosphate); methomyl (carbamate); imidacloprid (neonicotinoid); emamectin benzoate (avermectin); azadirachtin (tetranortriterpenoid), deltamethrin (pyrethroid) and fipronil (phenylpyrazole). was evaluated in the laboratory against larvae and adults of the red palm weevil, Rhynchophorus ferrugineus (Olivier), by using dipping food technique. The results showed that imidacloprid was the most toxic insecticide among the tested compounds against the larvae, followed by emamectin benzoate, deltamethrin and fipronil, whereas the $\mathrm{LC}_{50} \mathrm{~s}$ were $63.6,136.6,290.2$ and $773.78 \mathrm{ppm}$, respectively. The organophosphate insecticides, chlorpyrifos-ethyl and dimethoate were the less toxic compounds $\left(\mathrm{LC}_{50} \mathrm{~s}\right.$ were 2597 and $\left.8466 \mathrm{ppm}\right)$, against larvae. However, deltamethrin was the most toxic insecticids against the adult followed by emamectin benzoate and imidacloprid, whereas the $\mathrm{LC}_{50}$ s were 129.8, 136.6 and $287.3 \mathrm{ppm}$, respectively. The organophosphate insecticides, chlorpyrifos-ethyl and dimethoate, were still the less active compounds $\left(\mathrm{LC}_{50} \mathrm{~s}\right.$ were 790.4 and 11085 ppm) against the adults of $R$ ferrugineus. The results revealed that the adults were more sensitive to most of the tested insecticides compared with larvae except for imidacloprid and dimethoate. Moreover, by increasing time of exposure the toxicity of imidacloprid to both larvae and adults increased.
\end{abstract}

Keywords: Red palm weevil, relative toxicity, insecticides, date palm

\section{INTRODUCTION}

The date palm tree, Phoenix dactylifera L. is an important tree to the people all over the world especially to those of the Middle East. Red palm weevil (RPW), Rhynchophorus ferrugineus (Olivier), is one of the most destructive pests of date palm trees in Middle East and North Africa. It was first recorded in Egypt in 1993, now the weevil spread all over the palm cultivated area (Murphy and Briscoe 1999). The infestation cannot be noticed easily, so the grubs keep feeding with no apparent symptoms until it's too late. The problem is still growing and no clear sign of effective control is apparent, making the prospect of the date palm trees in Egypt risky. Early detection of the pest can save the palms; However, the early detection is difficult due to the latent symptoms of the infestation. This makes the problem of palm weevil management intricate (Faleiro et al. 1998 and 1999). Current tactics employed to manage the weevil are largely based on insecticide application. Insecticides are applied in a range of preventive and curative procedures designed to limit the infestation (Abuzuhairah et al., 1996). Recent researches have focused on integrated pest management (IPM) involving surveillance, pheromone lures, cultural control and chemical treatments for the management of R. ferrugineus (Abraham et al., 1998). The choice of the chemicals now regularly used in the field developed through laboratory work on promising compounds. For example, Abraham et al. (1975) evaluated seven insecticides for control of $R$. ferrugineus, three of them were effective (dichlorvos, trichlorphon and propoxure). Abraham and Vidyasagar (1992), reported that insecticides such as chlorpyrifos, endosulfan and methiothion at $0.1 \%$ are recommended for $R$. ferrugineus control. Cabello et al. (1997) and Kaakeh (2010), concluded that imidacloprid (Confidor) may be used to control all ages of $R$. ferrugineus larvae. Ajlan et al. (2000) suggested that a mixture of pirimiphosmethyl and either oxydemeton-methyl or trichlorphon is suitable to control the larval and adult stages of $R$. ferrugineus. Furthermore, Abdulsalam et al. (2001) and Keekh, 2010 mentioned that fipronil is a convenient insecticide to control different life stages of $R$. ferrugineus.

The aim of the present work is to evaluate the biological activity of eight compounds belong to different groups of insecticides against 20-days old larvae and adults of $R$. ferrugineus, in the laboratory, using dipping food technique. These insecticides are chlorpyrifos-ethyl, dimethoate, methomyl, imidacloprid, emamectin benzoate, azadirachtin, deltamethrin and fipronil.

\section{MATERIALS AND METHODS}

Insects:

The main culture of $R$. ferrugineus was reared on semi-artificial diet as described by Alfazairy et al. (2003). The culture started with specimens collected

\footnotetext{
${ }^{1}$ Department of Pesticide Chemistry and Toxicology,

faculty of Agricultural, Alexandria University, Egypt.

${ }^{2-}$ Department of Plant Protection, faculty of Agriculture,

Damanhour University

Received April 28, 2014, Accepted May 22, 2014
} 
from highly infested palm tree farms at Edko District, Al-Boheira Governorate, Egypt. Restriction measures and care performed during transportation and experimental work to prevent insect escaping. $R$. ferrugineus stages kept in glass Jars $(500 \mathrm{cc})$ having circular holes in the lid for ventilation. The culture maintained at $25 \pm 1^{\circ} \mathrm{C}, 70-75 \%$ R.H. The laid eggs collected and eggs maintained under similar conditions in Petri-dishs $9 \mathrm{~cm}$ diameter with wet filter paper, until hatching, then provided with semi-artificial media, larvae were placed individually in small plastic jars. Adults and 20-days old larvae were used for bioassay tests.

\section{Chemicals:}

Commercial formulations of deltamethrin (Decis $2.5 \%$ EC), imidacloprid (Sinodor 70\% W.G), emamectin benzoate (Proclaim 5\% W.G), dimethoate (Perfekthion 40\% EC), azadirachtin (Achook $0.15 \%$ E.C), chlorpyrifos-ethyl (Lirifos 48\% EC), fipronil, (Fipromex 20\% SC) and methomyl (Methmax 90\% SP) were obtained from Ministry of Agriculture, Cairo, Egypt.

\section{Bioassay:}

Laboratory trials conducted to evaluate the efficiency of insecticides dilutions using dipping food bioassay technique (Ajlan et al. (2000). Pieces of sugarcane stem were soaked for $1 \mathrm{~min}$. in different dilutions of the insecticides formulations. Larvae (20 days old) and/or adults were exposed to the treated sugarcane pieces. Every concentration was replicated three times.Similar pieces of sugarcane stem were soaked in distilled water and served as control. Insect stages were examined after $24 \mathrm{hr}$ from exposure and the percentages of mortality were recorded. The insect was considered dead if it neither moved nor responded by reflex movement, when touched.

Regression equations of normal equivalent deviates (y) versus $\log$ dose $(\mathrm{x})$, and $\mathrm{LC}_{50}$ values and their $95 \%$ fiducial limits, were estimated according to Finney (1971). Relative toxicity of the insecticide at the $\mathrm{LC}_{50}$ levels was also estimated.

\section{RESULTS AND DISCUSSION}

\section{Toxicity of insecticides to adults of $R$. ferrugineus.}

In terms of $\mathrm{LC}_{50}$, the data showed that pyrethroid insecticide (deltamethrin) was the most toxic insecticide to the adult of $R$. ferrugineus after $24 \mathrm{hr}$. of exposure to poisoned medium whereas the $\mathrm{LC}_{50}$ was $129.8 \mathrm{ppm}$, followed by emamectin-benzoate and imidacloprid. The organophosphate insecticides (dimethoate and chlorpyrifose-ethyl) were the less toxic insecticides, $\mathrm{LC}_{50}$ 's(11085 and $\left.790.4 \mathrm{ppm}\right)$. The rest of the tested insecticides were moderately toxic (Table 1).

\section{Toxicity of Insecticides to $R$. ferrugineus larvae}

Data of 20 days old larvae that feed on insecticides treated sugarcane showed that imidacloprid was the most toxic one in terms of $\mathrm{LC}_{50}$, followed by emamectin-benzoate. Fipronil and methomyl, were moderately toxic $\left(\mathrm{LC}_{50}=737.78\right.$ and $804.7 \mathrm{ppm}$, respectively). The organophosphate insecticides (dimethoate and chlorpyrifose-ethyl) were the less toxic insecticides ( $\mathrm{LC}_{50}$ 's were 8466 and $2597 \mathrm{ppm}$ ) after 24 hr of exposure (Table 2). However, the mortality of azadirachtin to the larvae were less than $50 \%$ after $24 \mathrm{hr}$ of the exposure and the $\mathrm{LC}_{50} \mathrm{~S}$ value reached $756.9 \mathrm{ppm}$ after 5 days exposure time.

The relative toxicity of the tested insecticides at the $\mathrm{LC}_{50}$ levels showed that the toxicity of imidacloprid, the most toxic insecticide against the larvae of red palm weevil, was about two times of emamectin-benzoate toxicity and about 4.6 fold of the deltmethrin toxicity, while it is about 133 fold of dimethoate toxicity, the least toxic insecticide against the larvae of $R$. ferrugineus. However the relative toxicity of the insecticides against the adults of $R$. ferrrugineus revealed that deltamethrin and/or emamectin-benzoate were the most toxic insecticides, whereas they are about two fold toxic of imidacloprid or fipronil, while they are about 85 fold toxic of dimethoate insecticide, the less toxic insecticide (Table 3 ).

The effect of exposure time on the toxicity of imidacloprid as one of the highly toxic insecticide against both adults and larvae, revealed that the toxicity increased with increasing the exposure time from $24 \mathrm{hr}$ to $48 \mathrm{hr}$. In the meantime, the data showed that the susceptibility of $R$. ferrrugineus larvae was more than the adults to this insecticide.

In general, the results showed that imidacloprid and emamectine-benzoate had a remarkable effect on 20 days old larvae or adults of $R$. ferrugineus after $24 \mathrm{hr}$ of exposure to poisoned medium. By increasing time of exposure, the toxicity of imidacloprid increased and that might depend on the amount of insecticide picked up by insects that might sufficient to suppress the biochemical targets. Data revealed that imidacloprid is potent for the larvae, thus, imidacloprid could break down the life cycle of $R$. ferrugineus and might be suitable to incorporate in the control programs of $R$. ferrugineus as a protective or curative agent. The extra usefulness could achieve if this insecticide implemented in the integrated pest management programs (IPM) that delivered to control the palm insect pests. The advantages of imidacloprid are its systemic properties, broad spectrum activity with relative low rate of application, long lasting efficacy and mode of action 
that different from organophosphates, carbamates and pyrethroids, in addition of low toxicity to mammals (Cox, 2001and Kaakeh, 2010). Furthermore, application technique could add another advantage, so drenched into the root zones of palm offer a practical solution for controlling some palm pests. Foliar application result in drift, which is especially objectionable in urban environment (Howard and Stopek, 1999) and trunk injections are not an option, because affect the beauty of palm trees. The concern about side effect of pesticides on the environment has resulted in the restriction in the use of many toxic products (Gush, 1997). Innovative soil application makes imidacloprid safer to beneficials and bee are not harmed, so that it is used for IPM programs (Zillekens, 2006). Lastly, current efforts are examining the potential developing of biopesticids and focused on IPM, involving surveillance, pheromone lures, cultural control and chemical treatments for the management of $R$. ferrugineus (Abraham et al., 1989, Moura et al. 1995, Abraham et al., 1998 and Keekh, 2010).

\section{Table1. Toxicity of insectcides to adults of $R$. ferrugineus after $24 \mathrm{hr}$ of exposure}

\begin{tabular}{|c|c|c|c|}
\hline Treatment & $\begin{array}{c}\mathrm{LC}_{50}(\mathrm{ppm}) \\
(95 \% \text { fiducial limits })\end{array}$ & $\begin{array}{c}\text { Regression of N.E.D (Y) } \\
\text { on log dose (X) }\end{array}$ & Slope \pm SD \\
\hline Imidacloprid & $287.3(247.5-333.7)$ & $Y=-4.7+1.9 x$ & $1.9 \pm 0.03$ \\
\hline Emamectin-benzoate & $136.6(96.1-193.8)$ & $\mathrm{Y}=-4.4+2.0 \mathrm{x}$ & $2.0 \pm 0.08$ \\
\hline Chlorpyrifose-ethyl & $790.4(670.2-931.9)$ & $Y=-5.6+1.9 x$ & $1.9 \pm 0.03$ \\
\hline Dimethoate & $11085(10045-12233)$ & $Y=-11.4 .9+2.8 x$ & $2.8+0.20$ \\
\hline Fipronil & $290.1(230.3-365.8)$ & $Y=-2.9+1.2 x$ & $3.2 \pm 0.10$ \\
\hline Deltamethin & $129.8(119.5-141.0)$ & $Y=-7.7+3.6 x$ & $3.6 \pm 0.06$ \\
\hline Azadirachtin & $708.9(694.2-724.1)$ & $Y=-47.6+16.7 x$ & $16.7 \pm 1.6$ \\
\hline Methomyl & $569.8(518.2-626.5)$ & $Y=-8.5+3.1 x$ & $3.1 \pm 0.07$ \\
\hline
\end{tabular}

Table 2. Toxicity of insectcides to larvae of $R$. ferrugineus after $24 \mathrm{hr}$ of exposure

\begin{tabular}{|c|c|c|c|}
\hline Insecticide & $\begin{array}{c}\mathrm{LC}_{50}(\mathrm{ppm}) \\
(95 \% \text { fiducial limits })\end{array}$ & $\begin{array}{c}\text { Regression of N.E.D (Y) } \\
\text { on log dose (X) }\end{array}$ & Slope \pm SD \\
\hline Imidacloprid & $63.6(54.2-74.5)$ & $Y=-4.3+2.4 x$ & $2.4 \pm 0.06$ \\
\hline Emamectin-benzoate & $136.6(96.1-193.8)$ & $\mathrm{Y}=-4.4+2.0 \mathrm{x}$ & $2.0 \pm 0.08$ \\
\hline Chlorpyrifose-ethyl & $2597(2053-3286)$ & $Y=-3.9+1.1 x$ & $1.1 \pm 0.02$ \\
\hline Dimethoate & $8466(8098-8851)$ & $Y=-27.7+7.1 x$ & $7.1 \pm 0.30$ \\
\hline Fipronil & $773.78(741.58-807.32)$ & $Y=-23.57+8.22 x$ & $8.22 \pm 0.41$ \\
\hline Deltamethin & $290.2(154.0-331.6)$ & $Y=-5.4+2.2 x$ & $2.2 \pm 0.03$ \\
\hline Azadirachtin\# & $756.9(732.1-782.5)$ & $Y=-24.1+8.3 x$ & $8.3 \pm 0.67$ \\
\hline Methomyl & $804.7(731.4-885.4)$ & $Y=-8.2+2.8 x$ & $2.8 \pm 0.06$ \\
\hline \multicolumn{4}{|l|}{ \# Mortality after 5 days. } \\
\hline \multicolumn{4}{|c|}{$\begin{array}{l}\text { Table 3. Relative toxicity of the insecticides at the } \mathrm{LC}_{50} \text { levels for larvae and adults of } \\
\text { ferrugineus }\end{array}$} \\
\hline \multirow[t]{2}{*}{ Insecticide } & \multicolumn{3}{|c|}{ Relative toxicity after $24 \mathrm{hr}$} \\
\hline & \multicolumn{2}{|c|}{ larve } & \\
\hline Imidacloprid & 1.0 & \multicolumn{2}{|c|}{2.2} \\
\hline Emamectin-benzoate & 2.2 & \multicolumn{2}{|c|}{1.1} \\
\hline Chlorpyrifose-ethyl & 40.8 & \multicolumn{2}{|c|}{6.1} \\
\hline Dimethoate & 133.1 & \multicolumn{2}{|c|}{85.4} \\
\hline Fipronil & 12.2 & \multicolumn{2}{|c|}{2.2} \\
\hline Deltamethin & 4.6 & \multicolumn{2}{|c|}{1.0} \\
\hline Azadirachtin & -- & \multicolumn{2}{|c|}{5.5} \\
\hline Methomyl & 12.7 & \multicolumn{2}{|c|}{4.4} \\
\hline
\end{tabular}





\section{REFERENCES}

Abdulsalam, K. S.; M. S. Shawi; M. M. Abo-El-Saad; M. A. Rezk, and A. M. Ajlan. (2001). Regent (fipronil) as a candidate insecticide to control red palm weevil, Rhynchophorus ferrigineus (Olivier). Ann. Agric. Sci., Ain Shams Univ., Cairo., Vol. 46 (2), 841-849.

Abraham, V. A.; K. M. Abdulla koya and C. Kurian (1975). Evaluation of seven insecticides for control of red palm weevil, Rhynchophorus ferrugineus. J. Plant Crops, 3:7172.

Abraham, V. A. and P. S.Vidyasagar (1992). Strategy for control of red palm weevil of date palm in the Kingdom of Saudi Arabia. Consultancy report submitted to the Ministry of Agriculture and water, Kingdom of Saudi Arabia. 36 pp.

Abraham, V. A.; M. A. Alshnaibi; J. R. Faleiro; R. A. Abozuhairah and P. S. P. V. Vidyasagar (1998). An Integrated management approach for red palm weevil Rhynchophorus ferrugineus Oliv. A key pest of date palm in the Middle East J. Agric. Sci. Sultan Qaboos University .3: 77-83.

Abuzuhairah, R. A.; P. S. P. V. Vidyasagar and V. A. Abraham (1996). Integrated pest management of red palm weevil Rhynchophorus ferrugineus (Olivier). In date palm plantations of the kingdome of Saudi Arbia. Proceedings, XX International Congress of Entomology, Firenze, Italy, 25-31 August, 541 pp.

Ajlan, A. M.; M. S. Shawir; M. M. Abo-Elsaad and M. A. Rezk (2000). Laboratory evaluation of certain organophosphorus insecticides against the red palm weevil, Rhynchophorus ferrugineus (Olivier). Scientific Journal of King Faisal University, Basic and Applied Sciences, 1: 119-130.

Alfazairy, A. A.; A.M. El-Minshawy; Hedaya H. Karam and R. Hendi (2003): An easy and cheap feeding diet of vegetable origin for rearing the red palm weevil, Rhynchophorus ferrugineus (Olivier), (Coleoptera:
Curculionidae) . The First Internationl EgyptianRomanian Conference, Zagazig, December 171-179.

Cabello, T.; J. De La Pena; P. Barranco and J. Belda (1997). Laboratory evaluation of imidacloprid and oxamyl against Rhynchophorus ferrugineus.Tests of Agrochemicals and cultivars, U.K., 18, 6-7.

Cox, C. (2001). Imidacloprid. J. of Pesticide Reform, 21(1): $15-21$.

Faleiro, J. R.; V. A. Abraham and M. A. Al-Shuaibi. (1998). Role of pheromone trapping in the management of red palm weevil. Indian Coconut Journal. September 1-3.

Faleiro, J. R.; M. A. Al-Shuaibi, V. A. Abraham, and T. Prem Kumar (1999). A technique to assess the longevity of the pheromone (Ferrolure) used in trapping the date red palm weevil Rhynchophorus ferrugineus Oliv. . Sultan Qabus University Journal for Scientific Research, Agricultural Sciences 4 (1): 5-9.

Finney, D. J. (1971). Probit analysis. Cambridge University, press, London $3^{\text {rd }}$ ed..318 pp.

Gush, H. (1997). Date with disaster. The Gulf Today, Septamber 29, p.16.

Howard, F. W. and A. Stopek (1999). Control of royal palm bug, Xylastodoris luteolus with imidacloprid. Palms, 43:174-176.

Kaakeh, W. (2010). Toxicity of imidacloprid to developmental stages of Rhynchophorus ferrugineus (L.) (Curculionidae: Coleoptera): Laboratory and field tests. J. Biopest. 3: 304-308.

Moura, J. L. J.; M. L. B. Resende and E. F. Vilela (1995). Integrated pest management of Rhynchophorus palmarum (L.) (Curculionidae: Coleoptera). In oil palm in Bahia. Anais da Sociedade Entomologica do Brazil, 24, 501-506.

Murphy, S. T. and B. R. Briscoe (1999). The red palm weevil as an alien invasive: biology and the prospects for biological control as a component of IPM. Biocontrol News and Information, 20: 35-46.

Zillekens, U. (2006). Confidor a new method of chemical control to red palm weevil (Rhynchopgorus ferrugineus ), Crop Protect., 25: 432-439 


\section{الملغص العرب}

\section{القيم المعملي لجصن المبيدك الهشربة ضشطوري اليرقة والهشرة الكاملة لمسوسة النخل الحمراء}

محمدشعوير، مصطفى عبد الطيف عبلسي، يحيي محمدسام

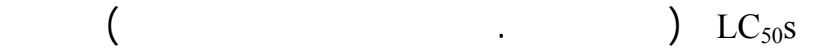
اليرقلت. ومن نلحية لخرى كان مبيد الدلتميثرين الألثثر سمية(ضد الهشرات البالغة يليه بنزوات الإيملمكتين وإميدلكلوبريد حيث كلت فئس

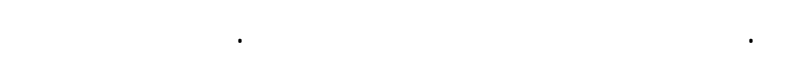

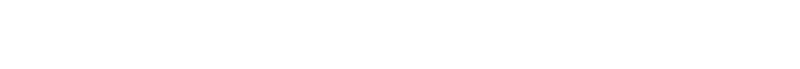

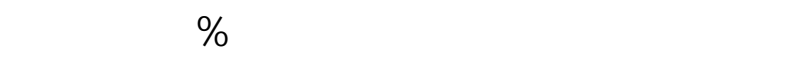

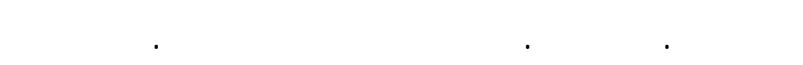
النتائج أن الهشرات الكلملة كلت لكثر هسلسية من اليرقت لمظم المبيدات الهشرية المختبرة بلستنناء إميدلكلوبريد

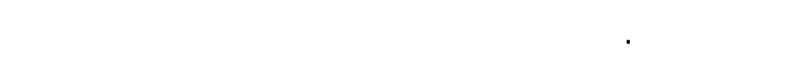

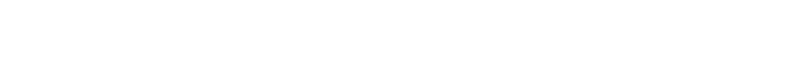

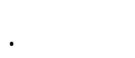

مق ققيم الشط الإبادي الحيوي لثمانية مركبلت تتنهي

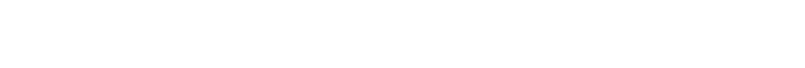
اليرقة عمر ·r يوم والعشرة الكملة معملياً بلستخدلم ققنية غمر الغذاء. وشملت المبيدات كل من الكلوربيريفوس إيثيل، داليميثويت(الفوسفات العضوية)؛ الميثومل (لكربلمات)؛

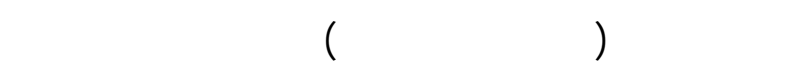
(أفيرميكتين)؛ الأذدرلكتين(التترالنورتراليتربينات)، دلتلميثرين التينين (بيريثرويد)، وفيبرونيل (فينايل بيرازول).

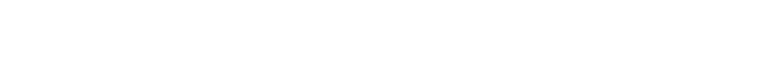
على اليرقات بين المركبك المختبرة يليه بنزئيدات الإيملمكتين، مُ الدلتميثرين وفيبرونل، حيث كلت قيم

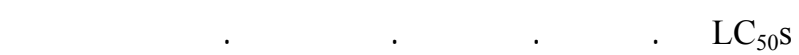
المليون على التوالي. كلتت مركببت الفوسفات العضوية، الكلوربيريفوس إيثل والدايميثويت أقل سمية حيث كلت الت التيفات 